\title{
Sea-spray aerosols and SARS-Cov-2: an analysis using AERONET data
}

Jacques Piazzola ( $\nabla$ piazzola@univ-tln.fr)

Mediterranean Institute of Oceanography https://orcid.org/0000-0001-8346-5732

\section{Christelle Desnues}

Mediterranean Institute of Oceanography: Institut Mediterraneen d'Oceanologie

\section{Philippe Parent}

CNRS: Centre National de la Recherche Scientifique

\section{Christophe Yohia}

Mediterranean Institute of Oceanography

\section{Elisa Canepa}

Consiglio Nazionale delle Ricerche

\section{Research}

Keywords: aerosols, sea-spray, SARS-Cov-2, AERONET

Posted Date: January 22nd, 2021

DOI: https://doi.org/10.21203/rs.3.rs-105929/v3

License: (c) (i) This work is licensed under a Creative Commons Attribution 4.0 International License. Read Full License 


\section{Abstract}

Even if the people density, habits and displacements probably represent the most important causes of the SARS-Cov-2 virus propagation, the role of the atmospheric aerosol in COVID-19 outbreaks is significant and it needs to be further investigated. Therefore, we aimed to study if the aerosol properties related to the different sources and meteorological conditions we can observe in continental and coastal urbanized areas can have an influence on the atmospheric transport of the SARS-Cov-2 virus. This paper focuses on the lockdown period to reduce the differences in the social behavior. As an example, we investigated the contamination cases during March 2020 in two specific French areas located in both continental and coastal areas with regard to the meteorological conditions and the corresponding aerosol properties. To this end, we used both the optical depth (AOD) and the Angstrom exponent provided by the AERONET network. The results show that the analysis of aerosol ground-based data can be of interest to assess a virus survey. In particular, our data show that moderate to strong onshore winds occurring in coastal regions, which allow large sea-spray production episodes, deal with smaller COVID-19 contamination rates. This suggests that the coagulation of SARS-Cov-2 viral particles with hygroscopic salty sea-spray aerosols would tend to inhibit its viral infectivity via possible reaction with $\mathrm{NaCl}$, especially in high relative humidity environments.

Capsule: Our results suggest that maritime air-masses limit the SARS-Cov-2 impact via the role of the seaspray.

\section{Introduction}

The COVID-19 escalation, which started in the beginning of 2020 is causing serious consequences on our society in terms of health with hundred thousands of deaths but also in terms of economy because of the confinement decision that nearly stopped the industrial and commercial activities of a large number of countries. In anticipation of another crisis in the future, we need to improve our knowledge of the spread of the SARS-Cov-2 and of potentially similar viruses, to help our governments to develop strategies avoiding as much possible stopping human activities. Since 2003, when the SARS-CoV was identified, very few studies and routine monitoring dealt with the role of coronaviruses in humans (Geller et al., 2012). SARS-Cov-2 is thought to spread through natural respiratory activities - such as breathing, talking, coughing, and sneezing - but, even if the recent study of Balachandar et al. (2020) focalized on the fluid dynamics of exhalations and subsequent dispersion processes, in practice little is still known about how the virus is spread through the air, both indoors and outdoors. Potential risk of airborne indoor transmission was demonstrated (e.g., Morawska et al., 2020). Indoor air environment is a mixing of indoor air pollution from specific sources and outdoor air pollution that penetrates indoors (NwanajiEnwerem et al 2020, Tofful et al., 2020). Therefore, even if the people density, habits and displacements probably represent the most important causes of the virus propagation, the influence of outdoor environmental parameters - like solar radiation, temperature, humidity, wind characteristics, pollution and aerosols load, etc. - need to be investigated as well in view of this containing strategy development. In particular, we need to explain why relatively close areas with similar socioeconomics properties knew very 
different situations in terms of the virus evolution. In this case, the role of secondary parameters needs to be studied. Among them, the atmospheric aerosol could have a strong impact through its role on respiratory diseases (e.g., Schwartz and Dockery, 1992; Dockery and Pope, 1994; European Environment Agency, 2019), and through aerosolization, which is an important air dispersal mechanism of infectious viruses, e.g., see Pyankov et al. (2018) for MERS-CoV. Yet, we suspect an influence of anthropogenic aerosols in the virus transmission since Romano et al. (2020) have recently suggested that a long-term average exposure to fine particles is associated with an increased risk of COVID-19. Furthermore, Conticini et al. (2020) investigated the correlation between the high COVID-19 lethality and the atmospheric pollution in Northern Italy, in which PM10 and PM2.5 were included, , and they concluded that the high level of pollution in that area should be considered an additional co-factor of the high lethality recorded. The accurate estimation of the impact of atmospheric aerosol properties on virus virulence and propagation, including SARS-CoV-2, is then an important scientific challenge (Setti et al., 2020; Contini and Costabile, 2020; Pozzer et al., 2020).

Regular aerosol observations based on well-calibrated instruments have led to a better understanding of the aerosol properties. In recent years, these instruments have played an important role in the determination of the increase of anthropogenic aerosols and of the quantification of the natural aerosols emissions by means of long-term studies. Among them, the AErosol RObotic NETwork (AERONET) program (http://aeronet.gsfc.nasa.gov/) aims to provide a global distribution of aerosol optical properties and to validate satellite retrievals. This network of ground observations provides suitable data for trend analysis of aerosol optical depth (AOD) at main wavelengths $(440,675,870$, and $1020 \mathrm{~nm})$ based on continuous long-term observations with high temporal resolution as well as high accuracy (e.g., Holben et al., 1998; Mallet et al., 2011).

To understand the influence of the aerosol composition and why the polluted areas are suspected to be more exposed to higher rates of contamination (Conticini et al., 2020; Contini et al., 2020), coastal regions are of particular interest to investigate since they are alternatively under influence of continental and marine air masses with respect to the wind direction. Indeed, the variation in wind direction is usually accompanied by changes of the atmospheric aerosol characteristics (e.g., Piazzola and Despiau, 1997), with potential different interactions with the virus. Thus, in coastal areas, aerosol concentrations result from complex mixing between particles produced by natural processes of continental and marine origins and particles of anthropogenic origin issued from urban and industrial activities. Among them, the seaspray aerosols generated at the air-sea interface by wave breaking represent a major component of the natural aerosol mass (Andreae, 1995; Yoon et al. 2007; Mulcahy et al., 2008; Piazzola et al., 2009). The generation of sea-spray is due to two major mechanisms: bubble-mediated production of jet and film droplets from breaking waves (e.g., Spiel, 1994; 1997), effective at wind speeds from $4 \mathrm{~ms}^{-1}$ and up, and production of spume droplets torn directly from wave crests by strong turbulence (e.g., Veron, 2015), 
effective at wind speeds in excess of 10-12 $\mathrm{ms}^{-1}$. Additional aerosols are produced over the Ocean's surface from secondary processes issued from gaseous dimethyl sulfide (DMS) released from surface waters (e.g., Bates et al., 1994). These primary and secondary marine aerosol production processes result in particles carrying widely in number and size, i.e., from less than $0.01 \mu \mathrm{m}$ to about $500 \mu \mathrm{m}$ (Van Eijk et al., 2011).

In this paper, we focus on the role of sea-spray aerosols in the SARS-CoV-2 propagation because it has been noted that the number of deaths in the French hospitals represents less than $15 \%$ of the total in regions with a maritime facade normalized to the people density (French Ministry of Health, 2020). We focus on the March-April period, which corresponds to the French lockdown and hence contributes to reduce the differences in the social behavior. As an example, Fig. 1 shows the normalized number (per 100.000 residents) of deaths due to COVID-19 by department in France from March to July 2020 (i.e., during the first wave). The COVID-19 effects tended to be larger in the inner areas than in the areas subject to marine influence. This calls for a study of the contamination rate of specific geographic areas with respect to the meteorological conditions and the corresponding air mass properties in order to better understand the role of sea spray in the virus propagation. To this end, we have compared two distinct French departments. The investigated pair is constituted by one coastal and one continental location. The continental French location is the Paris department, which was identified as a cluster for the pandemic with an excess in people hospitalizations and deaths. This is compared to the evolution of the contamination in the Loire-Atlantique department, a geographical area around Nantes, which is the largest and more industrialized city of the western part of France. This latter one was first preserved to the virus in the beginning of the pandemic, but then knew a sudden increase of the contamination cases

after the beginning of the confinement period, which was decided by the French government in the middle of March (i.e., the $17^{\text {th }}$ ). To investigate if the aerosol properties can play a role in these differences between coastal and continental regions, we have analyzed aerosol and meteorological data for every study area using ground-based measurements. The AERONET data allowed a survey of the aerosol properties, as optical depth (AOD) and Angstrom exponent in the selected locations during the spring 2020 COVID-19 outbreak. The present results are in favor of an influence of maritime air-masses on the limitations of the virus impact via the role of the sea-spray and atmospheric humidity.

\section{Field Sites And General Characterization Of The Study Areas}

We study both the meteorological characteristics and aerosol properties of two different specific geographical areas located in France. Our analysis focuses on the region around the city of Nantes, located in the French Atlantic shoreline, south of Brittany, and the inland Paris department (Fig. 1). The two French cities are both characterized by large traffic car and surrounded by industrialized areas. However, the Atlantic shoreline near Nantes, as the other French western regions, is most of the time under marine air masses influence, while the capital city is quite constantly polluted (von der WeidenReinmüller et al., 2014). The density of population is larger in Paris but there are not industrial activities in 
the center of the city. In coastal areas, the wind direction is the first parameter to consider in our analysis, since changes in wind direction may result in transport from different aerosol source regions. We will then study two particular types of meteorological conditions that often occur in the coastal area, offshore winds (which travel from land to the sea) and onshore winds (from the sea to the shore), which correspond to marine air mass conditions. Fig. 2 shows the normalized hospitalizations recorded in the Paris and Loire-Atlantique departments from March to May 2020. We note a factor of about seven between the two French regions all along the period. In particular, in the beginning of March, already few hundred cases were reported in Paris, whereas a few cases were detected in the Nantes region. Then a sudden increase of the COVID-19 contaminations and hospitalizations was recorded in the Nantes area. In this paper, we propose to investigate the reasons of this increase in terms of meso-scale atmospheric transport.

\section{Meteorological Conditions And Air Mass Properties}

The aerosol dynamics is strongly dependent on the meteorological conditions (e.g., Fitzgerald, 1991). In Fig. 3 is reported the temporal survey of both the wind speed and the direction measured in the period March-April 2020 in the coastal station - the SEM-REV site for multi-technology offshore testing - located in Le Croisic, twenty kilometers from Nantes near to the Atlantic shoreline (Fig. 3a) and in the centre of Paris (Fig. 3b). Fig. 3a exhibits two distinct periods: until the end of March, it shows that the wind comes from western to south-western directions resulting in the transport of marine air masses in the study area, then the dominant wind regime clearly becomes from East. In addition, we can note that in this first period, high wind speed episodes of onshore direction are frequent inducing both production and transport of sea-spray aerosols (e.g. Piazzola and Despiau, 1997). It should be also noted that such maritime conditions have also caused few rainy episodes. As outlined above, after about one month of purely marine regime, Fig. 3a shows that the wind direction turns East in the Atlantic shoreline. During this second period, the wind then keeps its direction for more than three weeks with rather low wind speeds. It should be noted that low wind speeds do not allow both a production of sea-spray at the airsea interface and also an efficient atmospheric mixing (e.g. Piazzola and Despiau, 1997). Indeed, the western part of France was first exposed to a long marine wind regime, followed by anthropogenized air masses, coming from the industrial region of Paris and its suburb. It should be noted that the decrease of the wind speed and change in wind direction exhibited in Fig. 3a at the end of March in Nantes seems to be well-correlated to the increase of the COVID-19 casualties, as noted in Fig. 2. In the meantime, Fig. 3b shows that Paris was exposed to east to south-east winds, which deal with land and urbanized influence. The wind speed never exceeded $6 \mathrm{~ms}^{-1}$ in March, which does not permit strong turbulent dispersion of atmospheric aerosols. However, the wind was rather high during fifteen days in April (Fig. 3b) and the COVID-19 cases did not really decrease in the meantime. There were therefore more opportunities for the wind to blow above the industrialized areas, as it will be confirmed from the air mass properties (see below). 
For each meteorological period presented in Figs. 3, we have studied the properties of the corresponding air masses using numerical calculations of the air mass back trajectories issued from the NOAA HYSPLIT model (Rolph et al., 2017; Stein et al., 2015). Fig. 4a reports air mass back trajectories in the French Atlantic shoreline for the first half of March 2020. As outlined above, it confirms that western winds recorded until the end of March (see Fig. 3a) deals with marine air mass coming from the open Atlantic Ocean. The first half of March probably allows transport of sea-spray aerosols in the low atmosphere in the Nantes region. In contrast, Fig. 4b, presents the air mass back trajectories calculated for the eastern wind period occurring in the second half of March, which indicates atmospheric transport to the Nantes region of anthropogenic air masses coming from Paris.

Fig. 5 presents the numerical calculations of the air mass back trajectories in Paris along March 2020. According to Fig. 5, which deals with the air mass back trajectories calculated for the second half of March, we see that most of the time, the air masses transported above the Paris area come essentially form the North-Western region, which deals mainly with urbanized areas and probably transport anthropogenic aerosols. It should be noted that the western influence that occurs in the west coast of France can also affect the center of the country in Paris as well, but in this latter case however, the wind has then the opportunity to cross polluted regions and transport anthropogenic aerosols.

\section{Survey Of The Aerosol Properties}

As noted in Section 3, combining the analysis of both the backtrajectory calculations and the meteorological conditions provide information on the composition of atmospheric aerosols transported in the regions investigated. To confirm our analysis and to study the influence of air masses on the propagation of the COVID-19 during spring 2020, we also used the global data provided by the AERONET network. This is equipped with sun-photometers that provide information of the aerosol properties above the region considered. This gives the total (columnar) Aerosol Optical Depth (AOD), which is defined as the integral of the extinction coefficient,

$\sigma_{e x t}$ along the air column from the ground to the top of the atmosphere:

$$
A O D=\int_{0}^{\infty} \sigma_{e x t} d z
$$

where $\sigma_{\text {ext }}$ is the extinction coefficient at altitude $\underline{\underline{z}}$

The size distribution of aerosols can be estimated from spectral AOD, typically from $440 \mathrm{~nm}$ to $870 \mathrm{~nm}$. The AOD is then strongly related to the aerosol concentrations and properties on the atmospheric column. The AERONET program has provided high quality aerosol data for the past decades over roughly 850 
global stations. We selected suitable AERONET stations having a sufficiently large record per month. The number of observations per month basically depends on the seasonal daytime length, the station's location, the operational instrument status, the cloud disturbance, and the verification process of data quality. From Eq.(1), we can readily calculate the AOD for each of the Sun-photometer bands at a specific wavelength $\lambda$, then by applying Angstrom Law. The Angstrom coefficient or exponent of Angstrom diffusion $a$, reflects the dependence between the aerosol optical thickness and the wavelength. It is defined as the variation of the diffusion coefficient between two wavelength such that:

$$
\alpha=-\frac{\ln \left(\tau_{1}\right)}{\ln \left(\tau_{2}\right)}
$$

where $\tau_{1}$ and $\tau_{2}$, the aerosol optical depth at wavelengths $\lambda_{1}$ at $\lambda_{2}$, respectively.

The Angstrom coefficient $a$, is then inversely related to the average particle size of the aerosol, i.e. the smaller the aerosols, the larger the coefficient. It is then a good indicator of the average distribution of aerosol concentrations. As an example, values of $a$ larger than 1 indicate the presence of small particles of anthropogenic or continental nature (as smoke particles and sulfates, e.g., Saha et al., 2008), more particularly if the AOD value is low in the meantime (typically $<0.2)$. In contrast, small values of $a(<1)$ indicate the presence of coarse mode particles such as desert dust and sea-spray (e.g., Dubovik et al. 2002). As for the marine particles generated by the breaking waves, they are generally large spherical aerosols, which also correspond to AOD (at $550 \mathrm{~nm}$ ) roughly smaller than 0.2 . In the maritime area, an industrial component may be accompanied by a variable marine component. If, like most of the time, the major contribution of marine aerosols is in the "coarse" mode, especially in the case of high relative humidity, we can still obtain a low Angstrom coefficient. As outlined above, the temporal evolution of both the Angstrom coefficient and the AOD can give an indication of the nature of the aerosols transported in the lower atmosphere. Moreover, by helping the analysis using the air mass backtrajectory calculations, the Angstrom parameter is enough in a first approach to characterize the size the atmospheric particles.

In Fig. 6 are reported the temporal variation of both the Angstrom coefficient and the AOD in Le Croisic over the period covering March 2020. We can note that Fig. 6 exhibits two distinct portions whenever we consider data recorded before or after about the 15 March. During the first two weeks of March, the value of the Angstrom coefficient stays smaller than about 0.5, with an AOD smaller than 0.2 , which indicates the presence of marine sea-spray in the coastal atmosphere. We can also observe in Fig. 6, however, that a progressive increase of the Angstrom coefficient above the value of one occurs after the $20^{\text {th }}$ of March, whereas the AOD increase in the meantime to vary around an average value of about 0.3 on the period. This sudden change in both the Angstrom coefficient and the AOD occurs at the date when the wind regime changes, as shown in Fig. 3a. In turn, this indicates a change in the aerosol characteristics shifting from a prevalence of natural sea-salt particles to anthropogenic ones. The change in the slope of 
the curve reported Fig. 6 corresponds to the sudden increase of the contamination cases in Nantes as shown in Fig. 3a.

Fig. 7 presents the temporal variation of both the Angstrom coefficient and the AOD in Paris along the period covering March 2020. The large Angstrom coefficient and small AOD observed in Fig. 7 then confirm the presence of a substantial anthropogenic contribution in the atmospheric aerosols all along March 2020. These aerosols are likely submicrometer particles of carbonaceous matter for a larger part, the major emission sources of soot particles in Europe being diesel engines and incomplete biomass burning. If we consider that the confinement had started the 17 March in France, we assume that the major part of the atmospheric aerosols is black carbon (BC) issued from wood burning emissions. Due to the low average temperature, the residential heating in Paris area had likely persisted during March 2020, while the traffic was almost stopped. The anthropogenic influence is shown to be nearly constant in Paris during the whole period. We can think that the emission of anthropogenic aerosols can be related to the continuous increase of the COVID-19 contamination as observed in the French capital city (see Fig. 1). We could note that the Angstrom coefficient is positively-correlated with the number of contaminations.

\section{Discussion}

Transmission of SARS-CoV-2 by aerosol emitted from human respiratory system and its viability have been supported by several recent studies (e.g., Guo et al., 2020; van Doremalen et al., 2020; Chia et al., 2020), but the whole set of parameters influencing its atmospheric propagation and their role are poorly understood (Sagripanti and Lytle, 2020; Schuit et al., 2020; Ratnesar-Shumat et al., 2020; Cacho et al., 2020), and it is often a specific combination of them, characterizing specific atmospheric air masses, that leads to enhanced incidence of infectious diseases (Hochman et al., 2021). The aim of this work was to study the environmental conditions via the role of atmospheric aerosols on SARS-CoV-2 propagation and activity. To this end, we have compared two regions experiencing different atmospheric air masses and with contamination rates that could be only partially explained by human densities and activities. This work has implications on transmissibility because the potential risk of airborne indoor transmission was demonstrated (e.g., Morawska et al., 2020), and indoor air environment is a mixing of specific indoor components emitted by indoor sources and outdoor air, including outdoor aerosol particles, that penetrates indoors (Nwanaji-Enwerem et al 2020, Tofful et al., 2020).

Meteorological conditions near the coastal city of Nantes exhibit two distinct periods, which exactly corresponds to an abrupt change in aerosol properties as indicated by the temporal evolution of both the Angstrom and the AOD during the same period (Figs. 6). This also corresponds to a net increase of the COVID-19 cases in this western part of France observed in the second half of March (Fig.2). After two weeks, changes in wind regimes (Fig. 3a), i.e., from onshore to offshore winds, induces a return of air 
mass conditions to a maritime character, and hence, a lower slope of the contamination cases was noted from the end of April.

In the meantime, continental sites such as the Paris region stay most of the time under influence of anthropogenic air masses. The anthropogenic character of aerosols transported above the location is also confirmed by the study of the Angstrom coefficient, which attests the presence of a substantial anthropogenic contribution in the atmospheric aerosols all along March 2020. This confirms that the virus action (indirect effect) could be favored by the presence of polluted aerosols (e.g., Romano et al., 2020; Isaia et al., 2020).

We hypothesize that the lifetime and viability of the virus in the atmosphere depends also on its ability to coagulate with aerosols. The coagulation is a phenomenon corresponding to the shock between two particles, which remain linked to form one particle. Coagulation is conditioned by the Brownian agitation of the air which takes into consideration the cross section of the particle and the collision probability of two particles. It can be expressed as the transverse area that the incident particle must hit in order for a collision to occur. According to the coagulation coefficient we can show (e.g., Fuchs, 1964) that the most rapid coagulation concerns particles of size about $0.1 \mu \mathrm{m}$, wich corresponds to the diameter of the SARSCoV-2 particle. Coagulation then acts a source and a sink for particles in the $0.02-0.15 \mu \mathrm{m}$ size range (Raes et al., 1995). Dusek et al. (2011) suggest that size is the key parameter for cloud-nucleating ability of aerosol particles, more than their composition. Fig. 8 reports a typical aerosol size distibution measured in coastal zones. We can see that if the lower size of atmospheric particles can be small as 10 $\mathrm{nm}$, sea salt are essentially supermicrometer aersosols with sizes up to $50 \mu \mathrm{m}$. The submicronic particles mainly deal with anthropogenic aerosols. In urban atmosphere, the anthropogenic particles, as carboneaous particles, present in the atmosphere have sizes close to the diameter of the virus particle and hence, can allow its transport through coagulation processes. This supports the hypothesis that the atmospheric transport of the virus is favored by polluted aerosols (Moreno et al., 2020). In addition, anthropogenic aerosols will increase the sensitivity of the fragile people to develop virus disease (Reinmuth-Selzle et al., 2017), worsening the number of cases and fatalities. In this latter case, we suspect a strong role of carbonaceous anthropogenic aerosols emissions, which allow better atmospheric transport of the SARS-CoV-2 through their fractal aspect by facilitating the aggregation of some viruses on it. The major emission sources of soot particles in large parts of Europe are diesel engines and incomplete biomass burning. An abundant constituent in atmospheric aerosols is carbonaceous matter (CM), which is composed of black carbon (BC) and organic carbon (OC). BC is commonly referred to as soot, whose sub-micrometer size and fractal morphologies may favor efficient interactions with the virus and its coagulation upon the particle. As the confinement had started the $17^{\text {th }}$ March in France, it suggests that the major part of the atmospheric aerosols is black carbon (BC) issued from wood burning emissions, in particular if we consider that the wood heating (residential heating) in 
Paris still persisted during March 2020, whereas the traffic jam was almost stopped. It should be noted that another continental example can be found in the literature, which had approximately the same behavior as Paris (see Conticini et al., 2000), with a similar polluted character of the air masses transported above the city during the period. In contrast, in coastal areas, the contamination rate can be low reflecting a potential consequence of viral activity inactivation by maritime air masses. In addition to the size, the morphology of the aerosols can also affect the coagulation process. The morphology of seasalt is cubic and flat whereas the soot has a complex form, as shown in Fig. 9 which reports SEM photographs of aerosols samples acquired using a Dekati imapctor (e.g., Piazzola et al., 2012) on the Mediterranean island of Porquerolles (Bruch et al.., 2020). The fractal aspect of the carbon particles could indeed, facilitate the aggregation of some viruses on it.

It should be noted that Fig 9 shows pictures of samples taken on a filter on which aerosols are mixed, but it is not demonstaretd in the atmosphere. However, if an external mixing between sea-salt and soot occurs in the atmosphere, we can imagine that the virus aggregate on the soot could be affected by the humidity of the sea-spray aerosol. In particular, if we consider that high wind speed periods of marine winds induce increase of the ambient relative humidity (Piazzola et al., 2003). Survivability of enveloped viruses, such as SARS-CoV-2, seems to be linked to temperature and humidity in a complex and nonmonotonic manner (Geller et al., 2012; Wang et al., 2020). As an example, Ma et al. (2020) and Wu et al. (2020) provided preliminary evidence that the COVID-19 pandemic may be partially suppressed with temperature and humidity increases.

Following the coagulation, atmospheric reaction between virus and sea-spray is also possible since seaspray is known to react with various atmospheric gas and aerosol components (see Piazzola et al., 2016 as an example). Sea salt aerosols are humid particles mainly constituted of sodium chloride ( $\mathrm{NaCl})$. Saltcontained aerosols can act as inhibitor factor for the virus activity. For instance, Quan et al. (2017) demonstrated that viruses captured on salt-coated filters exhibited rapid infectivity loss compared to gradual decrease on bare filters. Sea-spray aerosols constitute strongly hygroscopic particles that instantaneously answer to the humidity variations by varying in size (Fitzgerald, 1975). The increase in relative humidity induces an enhancement of the sea-spray sizes through the increase of the amount of the water vapor around the droplet. The radius of one sea salt particles at $100 \%$ of relative humidity is twice than this at a relative humidity of $80 \%$ (Lewis and Schwartz, 2004). Injection of a large volume of sea-spray particles in the atmosphere results in a larger ambient humidity in the lower atmosphere through aerosol evaporation. For onshore winds, high wind speeds are positively correlated with high relative humidity, as shown in Fig. 10, which presents the variation of the relative humidity when the wind speed of a marine direction increases in case of coastal marine air mass episode (this is not systematic for offshore winds, see Piazzola and Despiau, 1997). 
Chan et al. (2011) show that a high relative humidity $(>95 \%)$ combined to large temperature $\left(38^{\circ} \mathrm{C}\right)$ led to a $0.25 \sim 2$ loss of titer in 24 hours for the SARS coronavirus. Viral particles coagulated with sea-spray are surrounded by a very humid environment and it can be hypothesized that, in the marine atmosphere where a lot of large humid particles are present, virus infectivity will decrease rapidly. In contrast, even though humidity can be high in urbanized areas, the anthropogenic aerosols are mostly not hygroscopic and hence do not affect the infectivity of the virus. Kanji et al (2011) note that freshly emitted soot is hydrophobic. In addition, field observations show that, most of the time, small atmospheric particles do not answer to humidity (Dusek et al., 2006).

We therefore propose that the coagulation of the SARS-Cov-2 with anthropogenic aerosols protects the virus particle from ambient humidity and preserves its infectivity, whereas the coagulation with humid sea-spray rapidly inhibates its activity, in particular through the reaction of the salt with the virus. On the basis of our results, a main trend is emerging: the risk of ambient contamination by the SARS-CoV- 2 is less important for locations under marine air masse influence and more particularly when the wind speed is frequently strong enough to allow atmospheric transport of freshly produced sea-spray particles. In the coastal area that we considered, the contamination rate is low reflecting a potential consequence of viral activity reduction by maritime air masses. This is not hewever systematic for all maritime regions, since few of them are most of the time under influence of offshore winds as the Mistral for the Western Mediterranaean coast of France (near Marseille). Laboratory work is in progress to confirm our hypothesis on the role of the sea-spray aerosols on the survival of the SARS-Cov-2 virus in marine atmosphere.

\section{Conclusion}

The aim of this paper was to study the contamination rate of two different continental and coastal geographic areas with respect to the meteorological conditions and the corresponding air mass properties. The regions investigated in this paper were very different in terms of number of contaminations cases. Our results indicate that the risk of contamination by the COVID-19 was less important for the location under marine air masse influence and more particularly when the wind speed was frequently strong enough to allow atmospheric transport of freshly produced sea-spray particles. This reflects a potential consequence of viral activity reduction by maritime air masses. In view of the systematically lower number of cases is in this maritime area, we hypothesized an impact of the marine aerosol. Our results suggest that the marine air mass influence could have an effect on the SARS-CoV-2 through both the morphology and/or the hygroscopic character of sea-spray aerosols in the lower atmosphere, as well as a possible reaction with the salt onto the spray particles (Quan et al., 2017). It is then possible that marine episodes tend to decrease virus infectivity by coagulation of the virus with seaspray aerosols. In contrast, in polluted areas, the facilitated coagulation processes with non-hygroscopic anthropogenic aerosols makes the virus more infectious on larger periods. Being both effects more remarcable indoor where the virus concentration is more relevant. This is in addition to the combination 
with the capability of anthropogenic aerosols to increase the sensitivity of the fragile people to develop virus diseases (Reinmuth-Selzle et al., 2017). Further experiments will be required to assess the robustness of this approach for a better prediction of the SARS-COV-2 propagation and activity according to the trajectory and the nature of the air masses. If the present preliminary findings are confirmed, it should become then possible to identify the areas of greatest risk for COVID-19 propagations using forecasting of the main meteorological parameters and air quality. Work is currently in progress to confirm our hypothesis on the role of the sea-spray aerosols on the survival of the SARS-CoV-2 virus in marine atmosphere.

\section{Declarations}

Aknowledgements : This work was sponsored by ANR-ASTRID under contract ANR-18-ASTR-0002. The authors wish to thank Antoine Bertholon, Arnaud Blangy, Yves Perignon of the SEM-RV and Tathy Missamou for their help to the experimental effort in Le Croisic. Prs. François Ravetta. Jacques Pelon are gratefully aknowledged for the use of the AERONET data. The authors gratefully acknowledge the NOAA Air Resources Laboratory (ARL) for the provision of the HYSPLIT transport and dispersion model and/or READY website (http://www.ready.noaa.gov) used in this publication. A special think to Olivier Grauby for the SEM photographs.

Ethics approval and consent to participate : Not applicable

Consent for publication : Not applicable

Availability of data and material : Not applicable

Competing interests: Not applicable

Funding: This work was sponsored by ANR-ASTRID under contract ANR-18-ASTR-0002.

Authors' contributions: JP designed the research; JP, CY and EC collected data; JP, CD, PP and EC analyzed the data and wrote the manuscript. All authors discussed the results and contributed to the final paper. The author(s) read and approved the final manuscript. 


\section{References}

Andreae, M.O. (1995). Climate effects of changing atmospheric aerosol levels, in World survey of climatology, Vol. 16, Future climate of the world, edited by A. Henderson-Sellers, pp. 341-392.

Ahmed W., Angel N., Edson J., Bibby K., Bivins A., O’Brien J.W., Choi P.M., Kitajima M., Simpson S.L., Li J., Tscharke B., Verhagen R., Smith W.J.M., Zaugg J., Dierens L., Hugenholtz P., Thomas K.V., Mueller J.F (2020) First confirmed detection of SARS-CoV-2 in untreated wastewater in Australia: a proof of concept for the wastewater surveillance of COVID-19 in the community. Sci. Total Environ. 138764. doi: 10.1016/j.scitotenv.2020.138764.

Balachandar, S., S. Zaleski, A. Soldati, G. Ahmadi, L. Bourouiba (2020) Host-to-host airborne transmission as a multiphase flow problem for science-based social distance guidelines. International Journal of Multiphase Flow 132, 103439. https://doi.org/10.1016/j.ijmultiphaseflow.2020.103439

Bates, T.S., R.P. Kiene, G.V. Wolfe, P.A. Matrai, F.P. Chavez, K.R. Buck, B.W. Blomquist, and R.L. Cuhel, (1994) The cycling of sulfur in surface seawater of the Northeast Pacific. J. Geophys. Res., 99, 7,8357,843 .

Belosi, F., Marianna Conte, Vorne Gianelle, Gianni Santachiara, Daniele Contini, On the concentration of SARS-CoV-2 in outdoor air and the interaction with pre-existing atmospheric particles. Environmental Research 193 (2021) 110603

Bruch W., Piazzola, J., Branger, H., Luneau, L., Bourras, D, Tedeschi, G et A.MJ. van Eijk (2020) Spray Production Dependence on Wind and Wave Combinations : A Tunnel Study, submitted to Boundary Layer Meteorology.

Cacho, P.M., Hernández, J.L., López-Hoyos, M., Martínez-Taboada, V.M. (2020) Can climatic factors explain the differences in COVID-19 incidence and severity across the Spanish regions?: An ecological study. Environmental Health, 19:106

https://doi.org/10.1186/s12940-020-00660-4 
Chan, K. H., Malik Peiris, J.S., Lam, S.Y. Poon, L. L. M. Yuen, K. Y. and W. H. Seto (2011) The Effects of Temperature and Relative Humidity on the Viability of the SARS Coronavirus, Advances in Virology Vol. 7 pages https://doi.org/10.1155/2011/734690.

Chia PY, Coleman KK, Tan YK, et al. (2020) Detection of air and surface contamination by SARS-CoV-2 in hospital rooms of infected patients. Nat Commun.;11(1): 2800.

Conticini, E Frediani, B. and D. Caro (2020), Can atmospheric pollution be considered a co-factor in extremely high level of SARS-CoV-2 lethality in Northern Italy?, Environmental Pollution, Vol. 261, 114465 https://doi.org/10.1016/j.envpol.2020.114465.

Contini D. and F. Costabile (2020) Does Air Pollution Influence COVID-19 Outbreaks?, Atmosphere 2020, 11(4), 377; https://doi.org/10.3390/atmos11040377.

Dockery, D.W., Pope, C.A. (1994) Acute respiratory effects of particulate air pollution. Annu. Rev. Public Health, 15: 107-132.

Dubovik, O., Holben, B. N., Eck, T. F., Smirnov, A., Kaufman, Y.J., King, M. D., Tanre, D., and Slutsker, I (2002) Variability of ab-sorption and optical properties of key aerosol types observed inworldwide locations, J. Atmos. Sci., 59, 590-608.

Dusek, U. Frank, G. P. Hildebrandt, L. Curtius, J. Schneider, J. Walter, S. Chand, D. Drewnick, F. Hings, S. Jung, D. Borrmann S. and M. O. Andreae (2006) Size Matters More than Chemistry for Cloud-Nucleating Ability of Aerosol Particles, Science, New Series, Vol. 312, No. 5778, pp. 1375-1378.

European Environment Agency. Air Quality in Europe; EEA Report No 10/2019; Publications Office of the European Union: Luxembourg, 2019. 
Fitzgerald, J. W. (1991) Marine aerosols: A review, Atmospheric Environment, Volume 25, Issues 3-4, 1991, Pages 533-545.

Fitzgerald, J. W. (1975) Approximation formulas for the equilibrium size for an aerosol particle as a function of its dry size and composition and the ambient relative humidity. Journal of Applied Meteorology 14, 1044-1049.

Fuchs, N. A. (1964). The Mechanics of Aerosols. Pergamon Press, Oxford.

Geller, C., Varbanov, M., Duval, R. (2012) Human coronaviruses: insights into environmental resistance and its influence on the development of new antiseptic strategies. Viruses 4 (11), 3044-3068.

Guo Z-D, Wang Z-Y, Zhang S-F, et al (2020) Aerosol and surface distribution of severe acute respiratory syndrome coronavirus 2 in hospital wards, Wuhan, China, [published online ahead of print April 10,2020]. Emerg Infect Dis. 2020;26 (7).

Holben, B. N., Eck, T. F., Slutsker, I., Tanre, D., Buis, J. P., Setzer A., Vermore, E., Reagan, J. A., Kaufman, Y. J., Nakajima, T., Lavenu, F., Jankowiak, I., and Smirnov A (1998) AERONET-a federal instrument network and data archive for aerosol characterization, Remote Sens. Environ., 66, 1-16.

Hochman, A., P. Alpert, M. Negev, Z. Abdeen, A. Mohsen Abdeen, J. G. Pinto, H. Levine (2021) The relationship between cyclonic weather regimes and seasonal influenza over the Eastern Mediterranean. Science of the Total Environment 750, 141686 https://doi.org/10.1016/j.scitotenv.2020.14168600489697/

Isaia, G., H. Diémoz, F. Maluta, et al., Does solar ultraviolet radiation play a role in COVID-19 infection and deaths? An environmental ecological study in Italy, Science of the Total Environment (2020), https://doi.org/10.1016/j.scitotenv.2020.143757

Page 15/28 
Kanji, Z. A., Welti, A., Corbin, J. C. and Mensah, A. A. (2020). Black carbon particles do not matter for immersion mode ice nucleation. Geophysical Research Letters, 46, e2019GL086764. https://doi.org/10.1029/2019GL086764

Lewis, E. R., and S. E. Schwartz (2004), Sea Salt Aerosol Production: Mechanisms, Methods, Measurements and Models-A Critical Review , Geophys. Mo nogr. Ser., vol. 152, 413 pp., AGU, Washington, D. C.

Lodder W and de Roda Husman A.M (2020) SARS-CoV-2 in wastewater: potential health risk, Lancet Gastroenterol. Hepatol. doi: 10.1016/S2468-1253(20)30087-X.

Ma, Y., Zhao, Y., Liu, J., He, X., Wang, B., Fu, S., Yan, J., Niu, J., Zhou, J., Luo, B. (2020) Effects of temperature variation and humidity on the death of Covid-19 in Wuhan, China. Sci. Total Environ. 724, 138226-138226.

Mallet, M. Gomes, L. Salmon, F. Sellegri, K. Pont, V. Roger J.C and J. Piazzola (2011) Calculation of key optical properties of the main anthropogenic aerosols over the Western French coastal Mediterranean Sea, Atmospheric Research, vol. 101, pp. 396-411.

Morawska, L., J.W. Tang, W. Bahnfleth, P.M. Bluyssen, A. Boerstra, G. Buonanno, J. Cao, S. Dancer, A. Floto, F. Franchimon, C. Haworth, J. Hogeling, C. Isaxon, J.L. Jimenez, J. Kurnitski, Y. Li, M. Loomans, G. Marks, L.C. Marr, L. Mazzarella, A.K. Melikov, S. Miller, D.K. Milton, W. Nazaroff, P.V. Nielsen, C. Noakes, J. Peccia, X. Querol, C. Sekhar, O. Seppänen, S.-i. Tanabe, R. Tellier, K.W. Tham, P. Wargocki, A. Wierzbicka, M. Yao (2020) How can airborne transmission of COVID-19 indoors be minimised? Environment International 142: 105832. https://doi.org/10.1016/j.envint.2020.105832

Mulcahy, J.P., O’Dowd, C.D., Jennings, S.G., and D. Ceburnis, D. (2008). Significant enhancement of aerosol optical depth in marine air under high wind conditions. Geophysical Research Letters, 35, L16810, doi; 1029/2008GL034303. 
Nwanaji-Enwerem, J.C., J.G. Allen, P.I. Beamer (2020) Another invisible enemy indoors: COVID-19, human health, the home, and United States indoor air policy. Journal of Exposure Science \& Environmental Epidemiology 30:773-775. https://doi.org/10.1038/s41370-020-0247-x

Pyankov, O.V. Sergey A. Bodnev, Olga G. Pyankova, and I. E. Agranovskib (2018) Survival of aerosolized coronavirus in the ambient air, J Aerosol Sci. pp. 115: 158-163, doi: 10.1016/j.jaerosci.2017.09.009.

Piazzola, J., N. Mihalopoulos, E. Canepa, G. Tedeschi, P. Prati, M. Bastianini, P. Zampas, T. Missamou, L. Cavaleri (2016) Characterization of aerosols above the Northern Adriatic Sea: case studies of offshore and onshore wind conditions. Atmosp. Environment, 132, 153-162.

Piazzola, J., Sellegri K., Bourcier L., Mallet M., Tedeschi, G., Missamou, T (2012) Physicochemical characteristics of aerosols measured in the spring time in the Mediterranean coastal zone"doi.org/10.1016/j.atmosenv.2012.02.057 Atmospheric Environment,54,545-556.

Piazzola, J., Forget, P., Lafon, C., and Despiau, S., (2009). Spatial Variation of Sea-Spray Fluxes over a Mediterranean Coastal Zone Using a Sea-State Model. Boundary-Layer Meteorology, 132 (1), 167-183.

Piazzola, J. Bouchara, F. Van Eijk A.M.J. and G. De Leeuw (2003) "Development of the Mediterranean extinction code MEDEX," Optical Engineering, vol. 42, n 4, pp 912-924.

Piazzola J., A.M.J. Van Eijk and et De Leeuw G. (2000) An extension of the Navy Aerosol Model (NAM) to coastal areas, Optical Engineering vol 39, n6, pp. 1620-1631.

Piazzola, J., and Despiau, S., (1997) Contribution of marine aerosols in the particle size distributions observed in Mediterranean coastal zone. Atmospheric Environment, 31 (18), 2991-3009.

Pozzer, A., Dominici, F., Haines, A., Witt, C., Mùnzel, T., Lelieveld J. (2020) Regional and global contributions of air pollution to risk of death from COVID-19. Cardiovascular Research, 
Quan, F.-S., Rubino, I., Lee, S.-H., Koch, B. and Hyo-Jick Choi (2017) Universal and reusable virus deactivation system for respiratory protection, Scientific reports 7:39956, DOI: 10.1038/srep39956.

Ratnesar-Shumate, S., G. Williams, B. Green, M. Krause, B. Holland, S. Wood, J. Bohannon, J. Boydston, D. Freeburger, I. Hooper, K. Beck, J. Yeager, L.A. Altamura, J. Biryukov, J. Yolitz, M. Schuit, V. Wahl, M. Hevey, P. Dabisch (2020) Simulated Sunlight Rapidly Inactivates SARS-CoV-2 on Surfaces. The Journal of Infectious Diseases, 222: 214-22. DOI: 10.1093/infdis/jiaa274

Raes, F., Wilson, J., and van Dingen, R (1995) Aerosol dynamics and it simplication for global aerosol climatology, in: Aerosol Forcingof Climate, (Eds) Charlson, R. J. and Heintzenberg, J., Wiley,New York.

Reinmuth-Selzle, K., Kampf, C.J., Lucas, K., Lang-Yona, N., Fröhlich-Nowoisky, J., Shiraiwa, M., Lakey, P.S. J., Lai, S., Liu, F., Kunert, A.T., Ziegler, K., Shen,F., Sgarbanti, F., Weber, B., IrBellinghausen, I., Saloga, Weller, M.G.J., Duschl,A., Schuppan, D and U. Pöschl (2017) Air Pollution and Climate Change Effects on Allergies in the Anthropocene: Abundance, Interaction, and Modification of Allergens and Adjuvants, Environ Sci Technol. 2017 Apr 18; 51(8): 4119-4141. Published online 2017 doi:

10.1021/acs.est.6b04908.

Rolph, G., Stein, A., Stunder, B. (2017) Real-time environmental applications and display sYstem: READY. Environ. Model. Software 95, 210-228. https://doi.org/10.1016/j.envsoft.2017.06.025.

Romano S..Becagli, S., Lucarelli, F., Rispoli, G and M.R.Perrone (2020) Airborne bacteria structure and chemical composition relationships in winter and spring PM10 samples over southeastern Italy, https://doi.org/10.1016/j.scitotenv.2020.138899.

Sagripanti, J.-L., C.D. Lytle (2020) Estimated Inactivation of Coronaviruses by Solar Radiation With Special Reference to COVID-19. Photochemistry and Photobiology, 96: 731-737. 
Saha, A. Mallet, M. Dubuisson, P. Piazzola J. and S. Despiau (2008) One year measurements of aerosol optical properties over an urban coastal site: Effect on local direct radiative forcing, Amospheric Research, vol 90, pp. 195-202.

Schuit, M., S. Ratnesar-Shumate, J. Yolitz, G. Williams, W. Weaver, B. Green, D. Miller, M. Krause, K. Beck, S. Wood, B. Holland, J. Bohannon, D. Freeburger, I. Hooper, J. Biryukov, L.A. Altamura, V. Wahl, M. Hevey, P. Dabisch (2020) Airborne SARS-CoV-2 Is Rapidly Inactivated by Simulated Sunlight. The Journal of Infectious Diseases, 222: 564-71. DOI: 10.1093/infdis/jiaa334.

Schwartz, J.; Dockery, D.W. (1992) Particulate Air Pollution and Daily Mortality in Steubenville, Ohio. Am. J., Epidemiology, 135, 12-19.

Setti, L and al. (2020) Searching for SARS-COV-2 on Particulate Matter:A Possible Early Indicator of COVID-19Epidemic Recurrence Int. J. Environ. Res. Public Health2020,17, 2986; doi:10.3390/ijerph17092986.

Spiel, D.E. (1994), The sizes of jet drops produced by air bubbles bursting on sea- and fresh-water surfaces, Tellus 46B, 325-3338.

Spiel, D.E. (1997), A hypothesis concerning the peak in film drop production as a function of bubble size, J. Geophys. Res. 102, 1153-1161.

Stein, A.F., Draxler, R.R., Rolph, G.D., Stunder, B.J.B., Cohen, M.D., Ngan, F. (2015) NOAA's HYSPLIT atmospheric transport and dispersion modeling system. Bull. Am. Meteorol. Soc. 96, 2059-2077. https://doi.org/10.1175/BAMS-D-14-00110.1.

Tofful, L., C. Perrino, S. Canepari (2020) Comparison Study between Indoor and Outdoor Chemical Composition of PM2.5 in Two Italian Areas. Atmosphere, 11, 368; doi:10.3390/atmos11040368 
van Doremalen N, Bushmaker T, Morris DH, et al. (2020) Aerosol and surface stability of SARS-CoV-2 as compared with SARS-CoV-1. N Engl J Med.;382(16):1564-1567.

van Eijk A.M.J., Kusmierczykand J.T and J. Piazzola (2011). The Advanced Navy Aerosol Model (ANAM): validation of small-particle modes. Proc. SPIE 8161, 816108; doi:http://dx.doi.org/10.1117/12.896178.

Veron, F., (2015). Ocean Spray. Annu. Rev. Fluid Mech., 47, 507-538.

von der Weiden-Reinmüller, S.-L.. Drewnick, F. Zhang, Q. J, Freutel, F., Beekmann M. and S. Borrmann (2014) Megacity emission plume characteristics in summer and winter investigated by mobile aerosol and trace gas measurements the Paris metropolitan area , Atmos. Chem. Phys., 14, 12931-12950, https://doi.org/10.5194/acp-14-12931.

Wang, B., H. Wu, X.-F. Wan (2020) Transport and fate of human expiratory droplets - A modeling approach. Phys. Fluids 32, 083307. https://doi.org/10.1063/5.0021280

Wu, Y., W. Jing, J. Liu, Q. Ma, J. Yuan, Y. Wang, M. Du, M. Liu (2020) Effects of temperature and humidity on the daily new cases and new deaths of COVID-19 in 166 countries. Science of the Total Environment, 729, 139051. https://doi.org/10.1016/j.scitotenv.2020.139051

Yoon, Y. J., Ceburnis, D., Cavalli, F., Jourdan, O., Putaud, J.P., Facchini, M.C., Decesari, S., Fuzzi, S., Sellegri, K., Jennings, S.G., and O'Dowd, C.D., (2007). Seasonal characteristics of the physicochemical properties of North Atlantic marine atmospheric aerosols,. Journal. Geophysical Research, 112, D04206, doi:10.1029/2005JD007044.

\section{Figures}




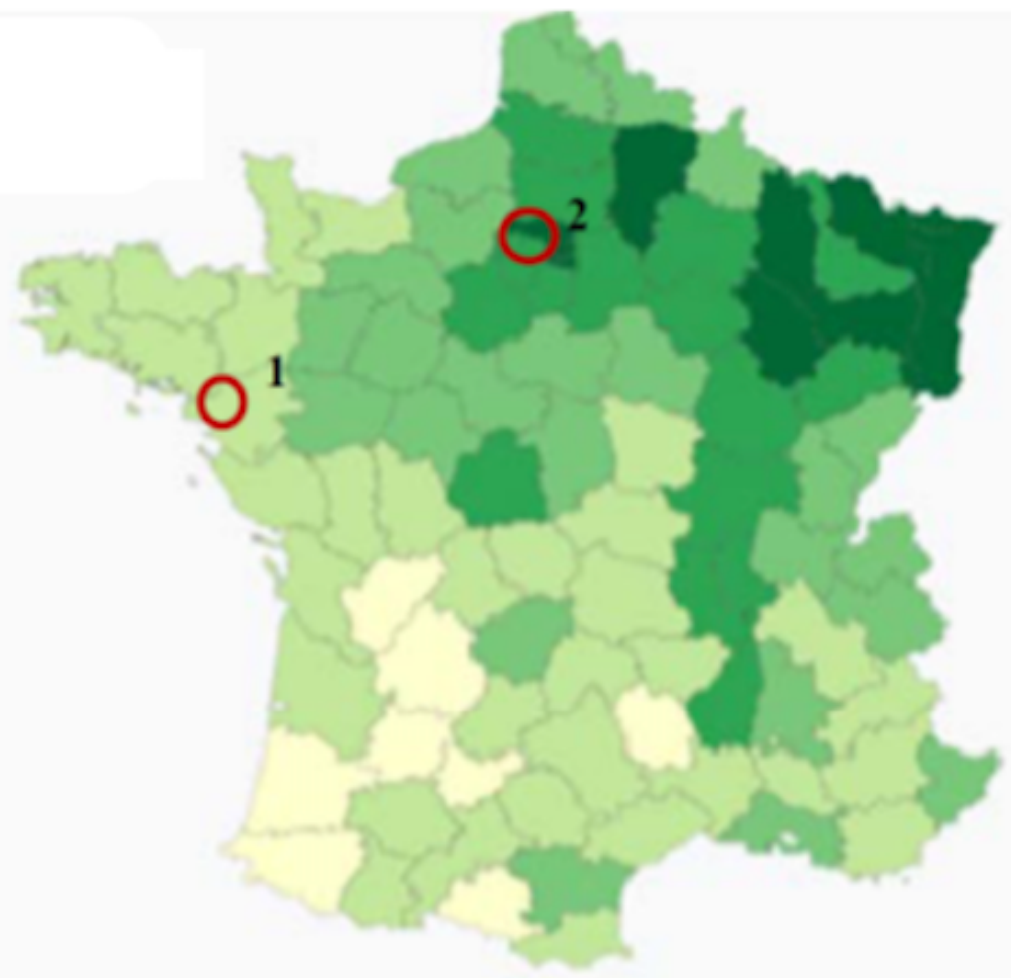

\section{$2020-07-03$ \\ $<4.38$ \\ $\geq 4.38$ \\ $\geq 13.57$ \\ $\geq 28.89$ \\ $\geq 50.34$ \\ 1100000}

\section{Figure 1}

Number of deaths per 100000 residents by French departments. The circles denote the cities investigated: 1 = Nantes, 2 = Paris. Images modified from https://en.wikipedia.org/wiki/COVID-19_pandemic_in_France 


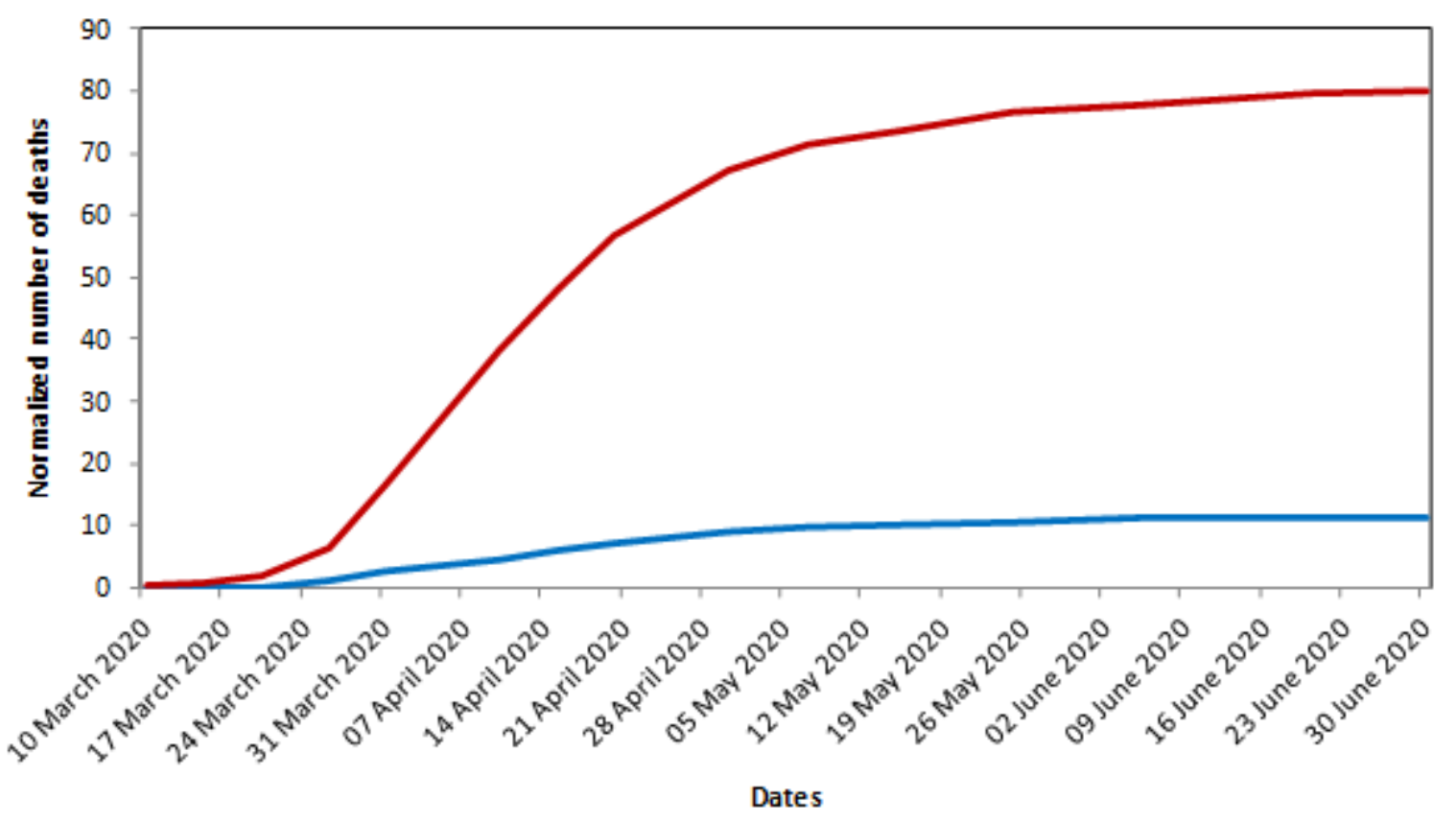

Figure 2

Number of deaths by COVID-19 per 100,000 residents by department in Paris (red line) and LoireAtlantique (blue line).
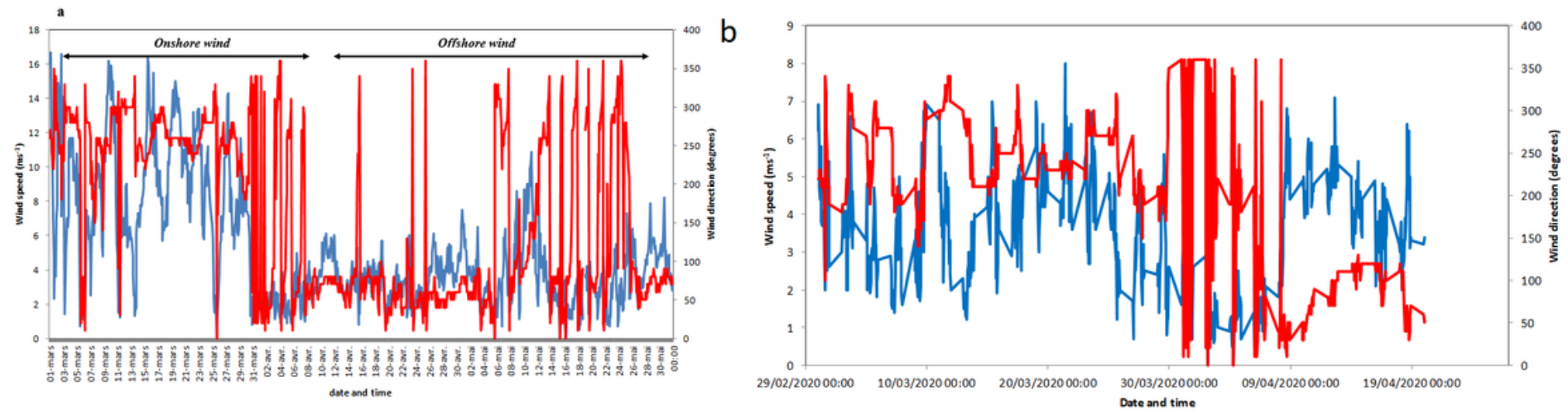

Figure 3

Temporal evolution of both the wind speed (the blue line) and direction (the red line) over March, April and May 2020 in (a) the SEM-REV- station located in Le Croisic near Nantes and (b) at the station of the Montsouris park in Paris. 
A

NOAA HYSPLIT MODEL

Backward trajectories ending at 1400 UTC 15 Mar 20 GDAS Meteorological Data

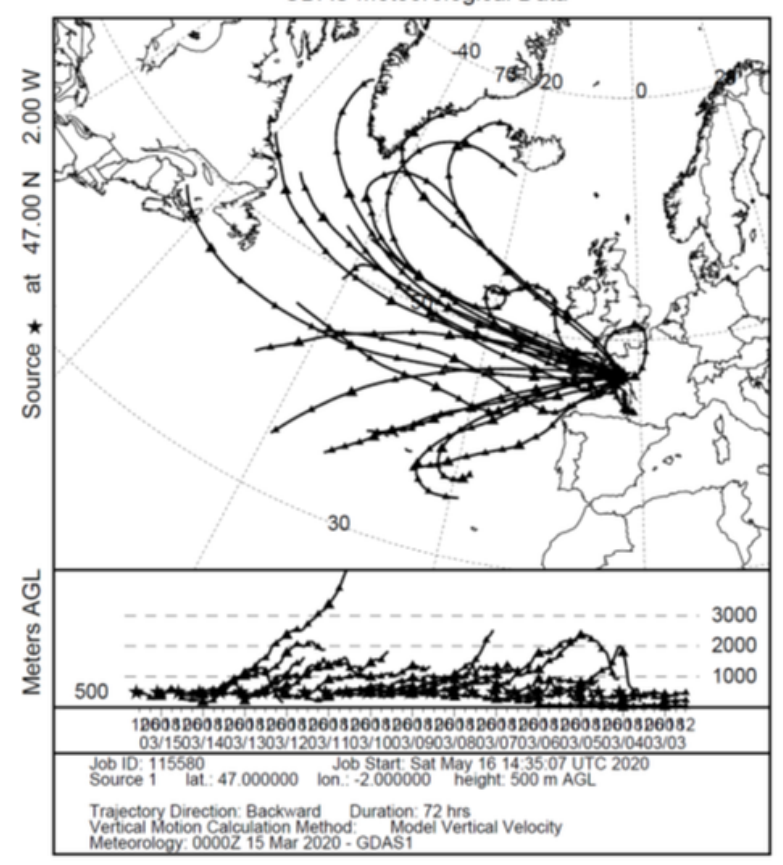

B

NOAA HYSPLIT MODEL

Backward trajectories ending at 1400 UTC 01 Apr 20

GDAS Meteorological Data

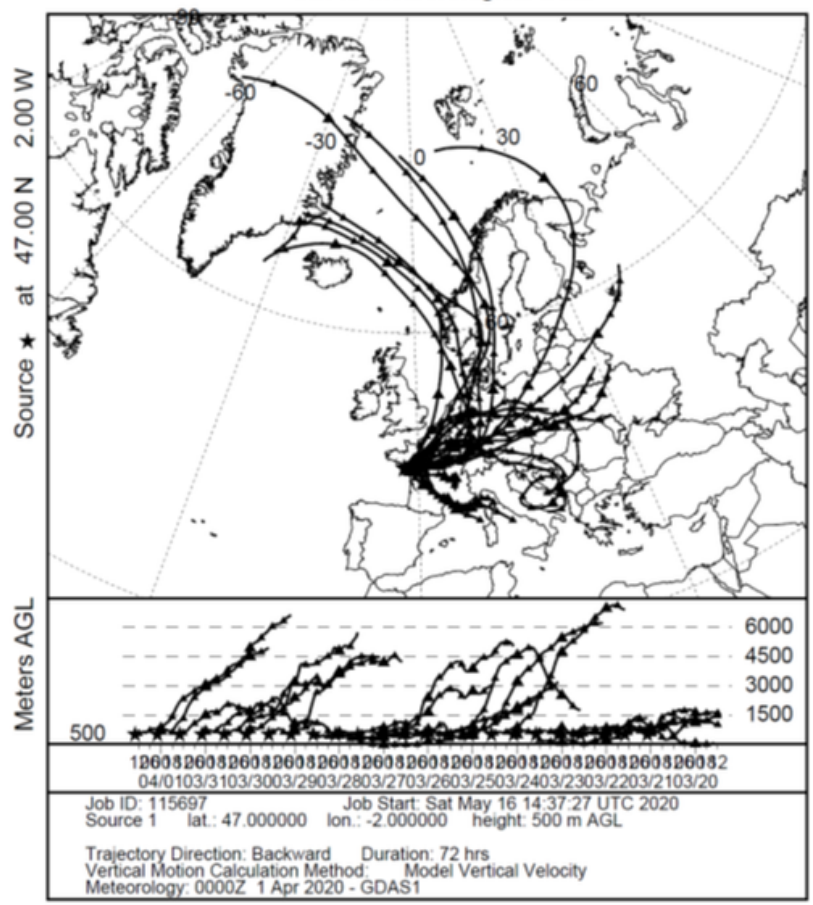

Figure 4

a: Calculated air mass back trajectories in Nantes (French Atlantic shoreline) for the first of March 2020. b : Calculated air mass back trajectories in Nantes (French Atlantic shoreline) for the second half of March 2020. 


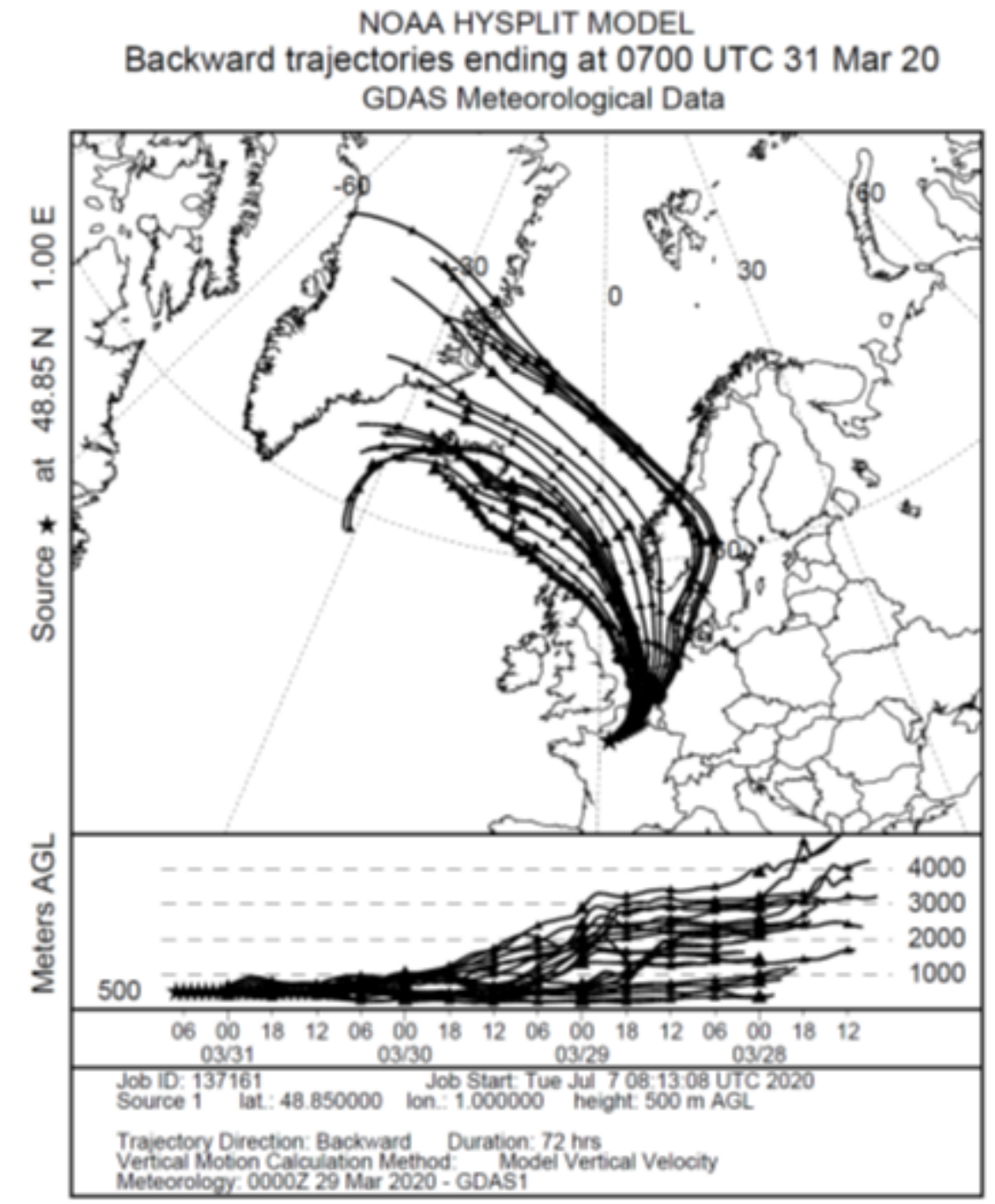

Figure 5

Calculated air mass back trajectories in Paris at the end of March 2020.
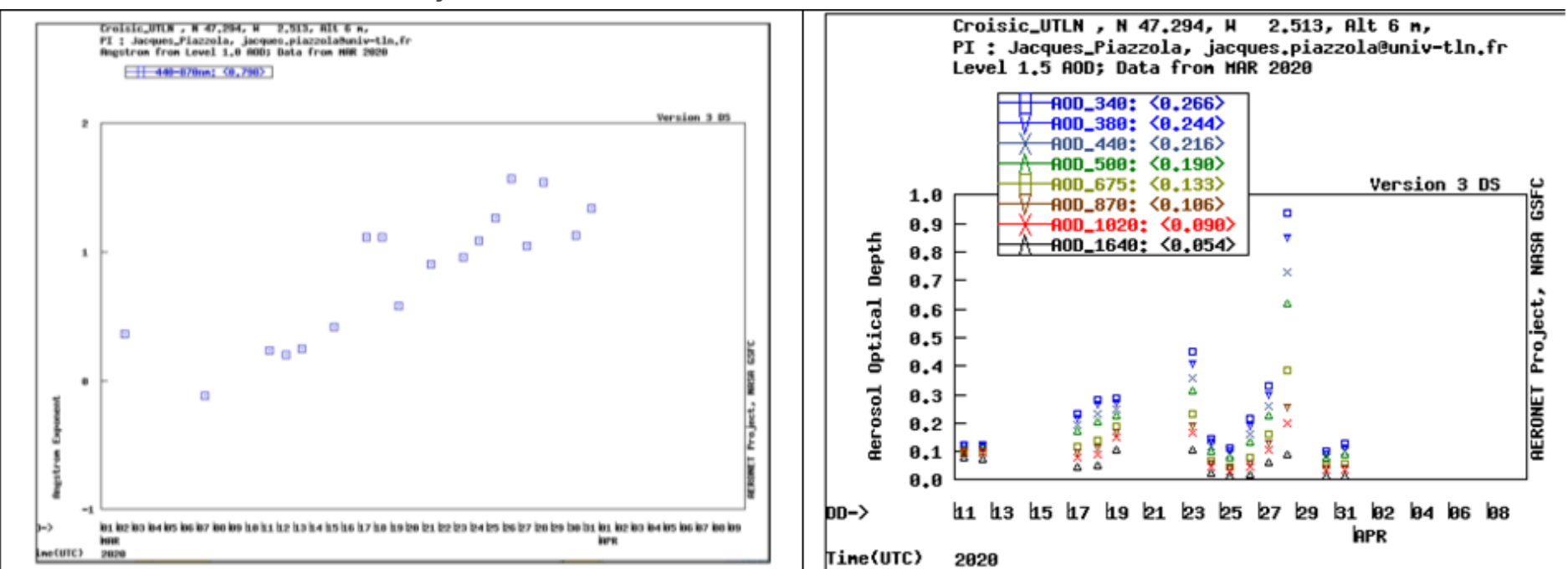

Tine(UTC) 2020 
Figure 6

Temporal survey of both the Angstrom coefficient (left) and the AOD (right) in Le Croisic (Nantes region) in March 2020.
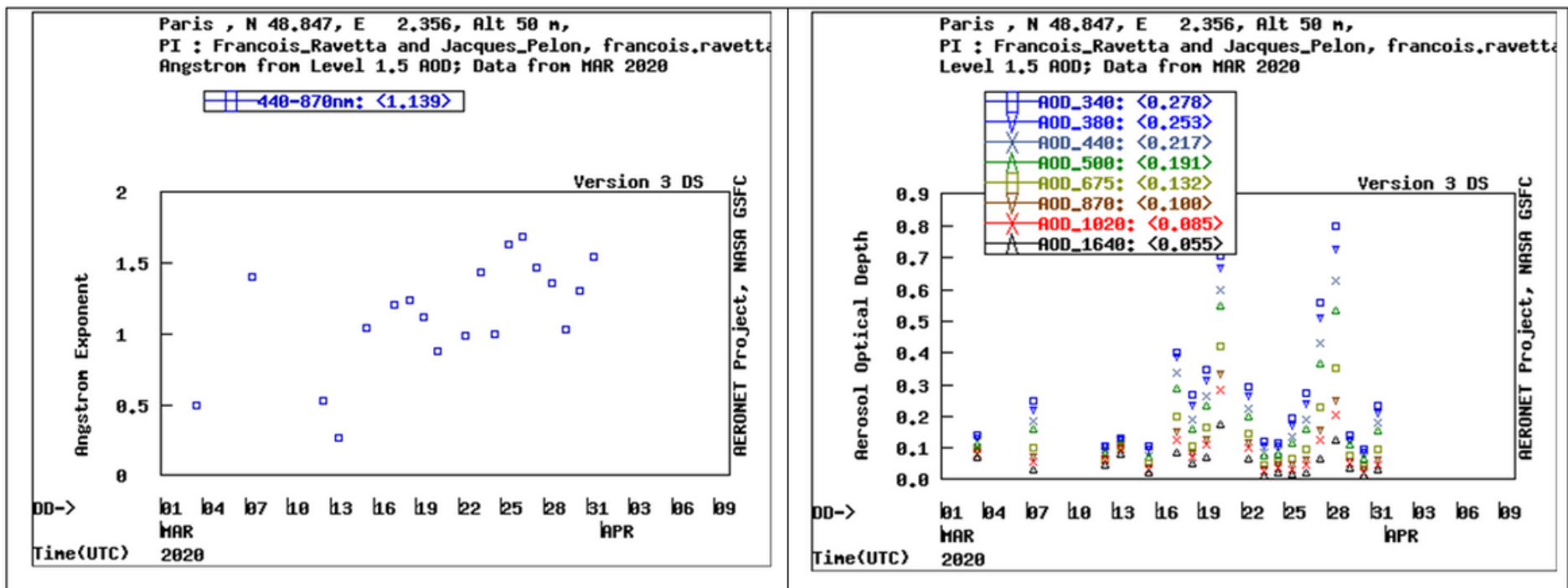

Figure 7

Temporal survey of the Angstrom coefficient (left) and the AOD (right) in Paris in March 2020. 


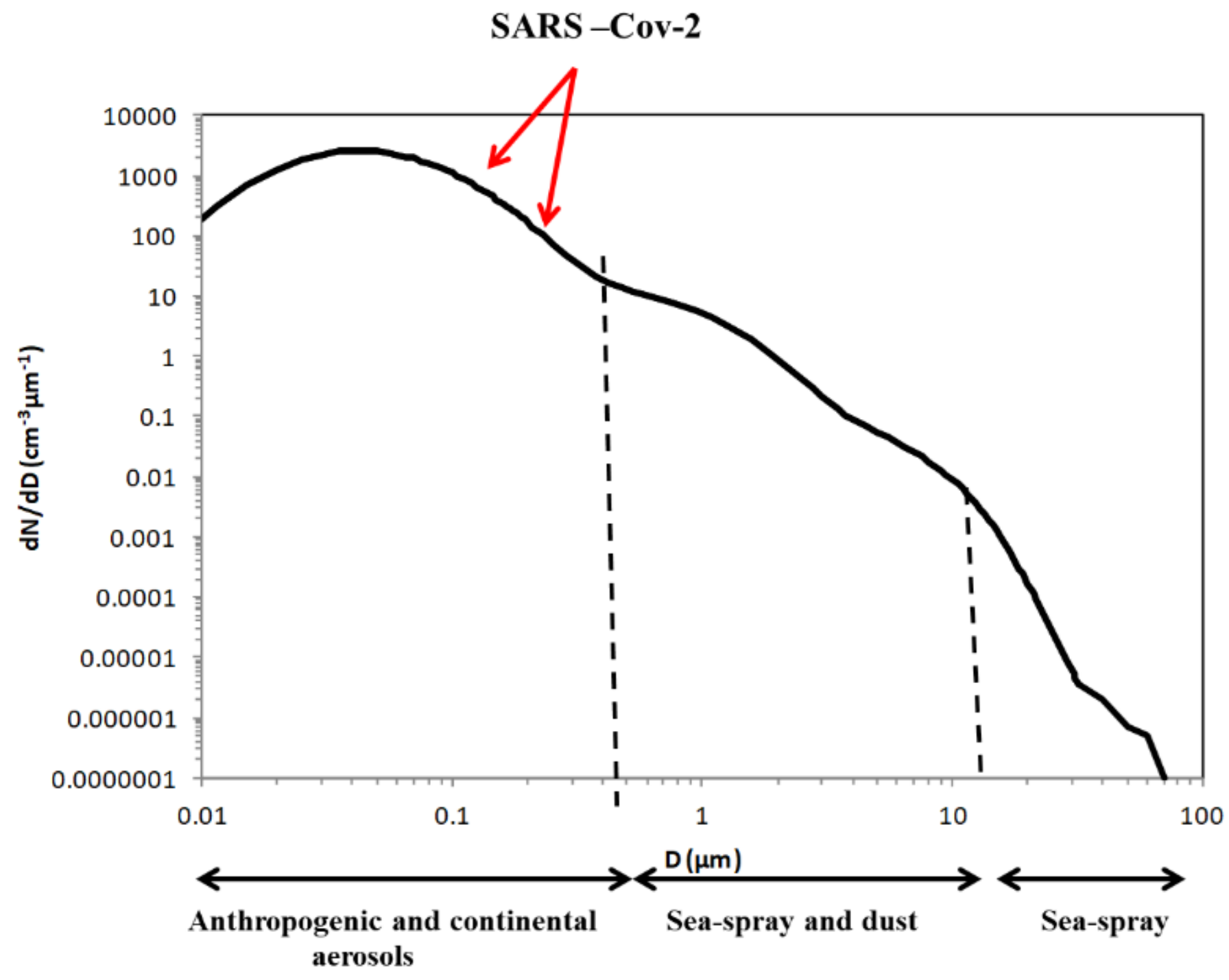

Figure 8

A typical aerosol size distribution measured in coastal area. The dashed lines indicate the size intervals dealing with the different aerosol sources found in the coastal zone. The arrows indicate the expected size of the SARS-CoV2 (around $100 \mathrm{~nm}$ ). 


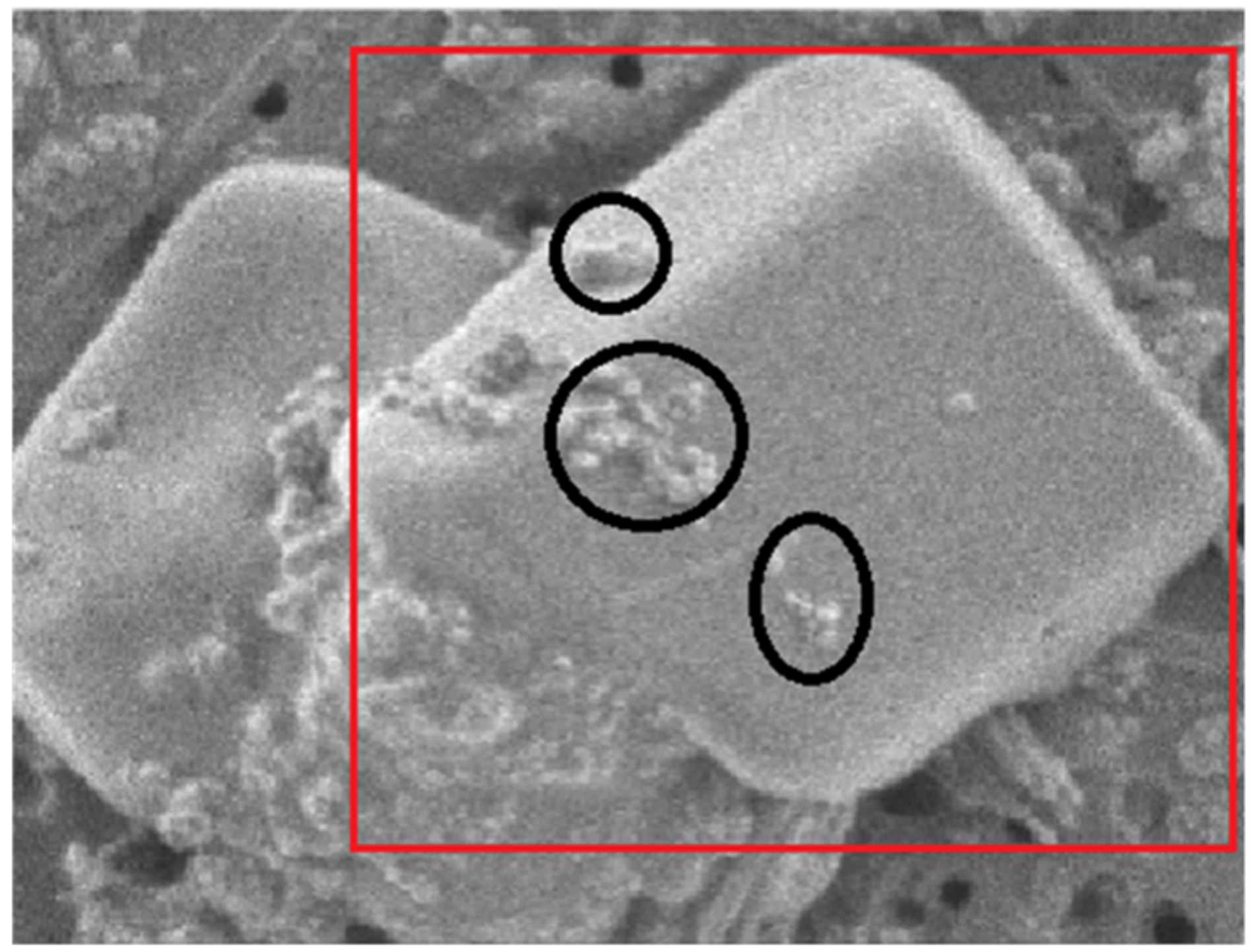

\section{Figure 9}

SEM images of a mixing sea-spray-soot as sampled on the Mediterranean coast using a Dekati impactor. The red square denotes a salt crystal, while the black circles show soot. 


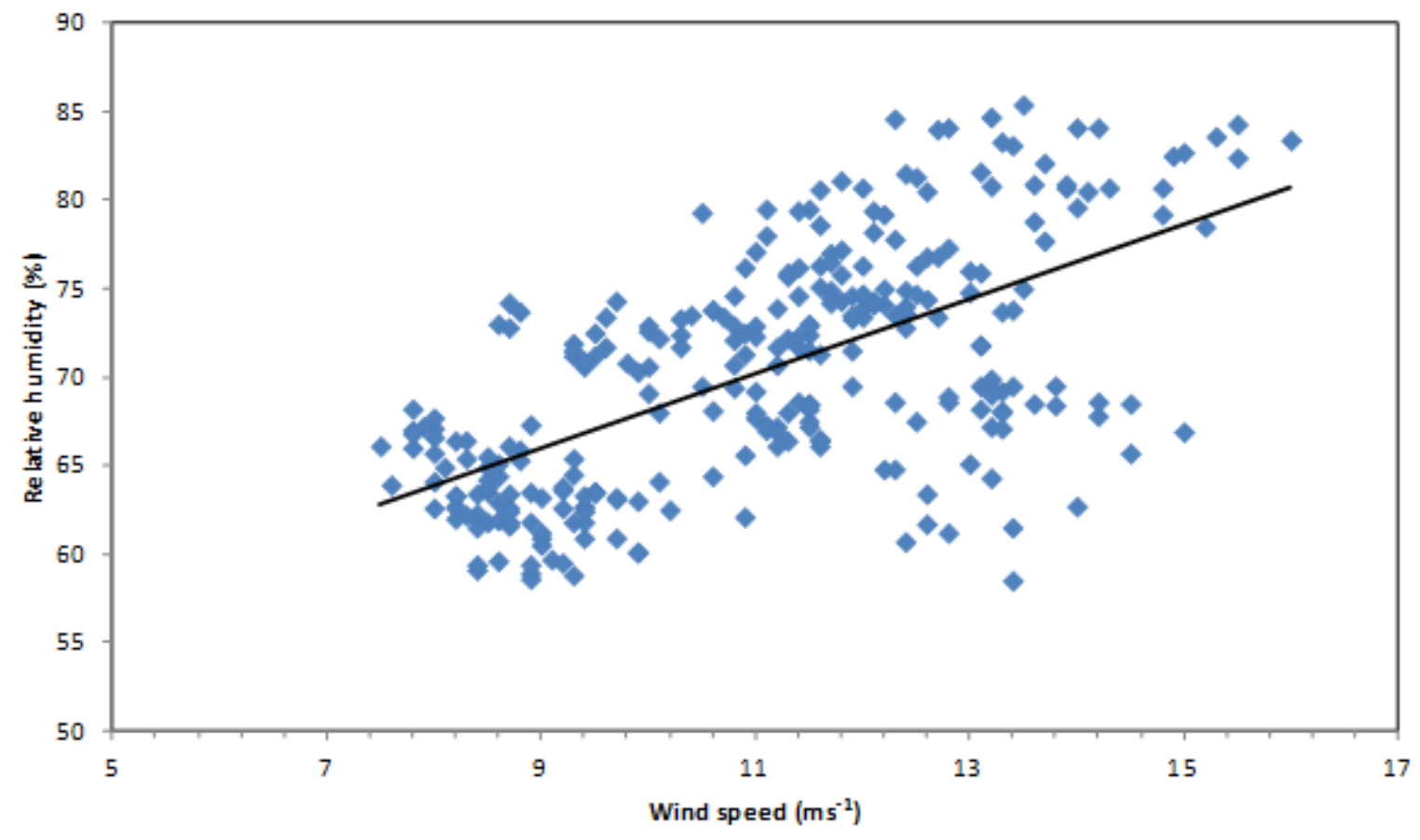

Figure 10

Variation of the relative humidity versus wind speed for an onshore wind direction (marine air mass episode). 